board covers of the one official text-book. The only questions he can allow are those he asks himself, for they are the only ones of which he can be sure of knowing the answers. So the classroom must become formal. At the stage of formalism, symbols have more meaning for children than at a dame school stage, but it tends to be a narrow and restricted meaning. Classroom facts and skills are thin disparate things that mesh poorly with one another and scarcely at all with the warm rich world of the child's personal lifo.

It is tempting to try to find a short cut from the dame school stagc or the lower levels of the stage of formalism to the best of modern teaching methods, but there seems little hope of this if the difficulty to be overcome is really the meagre education of the teachers who are themselves the products of the schools ono is setting out to roform. With help and advice, the stage of formalism can certainly be reduced in length, but the reform of a school system is a skilled and delicate business, where too much haste can create confusion, and where our own unanalysed experience may not always be the best of guides. The difficulty is increased by the fact that not all the teachers in a system at any moment have the same capacity to take up new and complex methods.

A new element of urgency has developed with the explosive demand for education in newly independent States that has been one of the striking characteristics of the past decade. The demand for education, indeed, has become a new political force in the world, a force that no democratic Government can long resist, and countries are sometimes driven to launch ambitious schemes of universal education before they have teachers with enough education to make them effective. Unless there is to be a great waste of effort and grievous disappointment with the results of popular education in emergent countries, there is urgent need for a scholarly study, from a new and practical angle, of the whole natural history of the educational systern and of the factors that help or retard its progress from stage to stage.

\title{
EXPECTATION OF LIFE IN THE UNITED STATES
}

\begin{abstract}
A RECENT report issued by the Metropolitan Life Insurance Co., New York, directs attention to the fact that the average length of life (expectation of life at birth) among industrial policy-holders reached a new record of 70.5 years in $1960 *$. This is slightly above the figure for 1959 , and only half a year greater than that for 1955. But although recont increases have been limited, long-term gains have been very impressive. Five years have been added to the average length of life of these policy-holders since 1946, ten years since 1937, and twenty-four years since 1909. In 1879-94, the earliest period for which data are available, the average lifetime was only 34 years-less than half that for 1960 .

The largest gains in expectation of life have occurred at the younger ages. Thus, at the age of 5, the figure for 1960 was 5.9 years greater than that two decades ago. At the age of 40 , the increase since 1940 has been $4 \cdot 3$ years, while at 65 the average future lifetime of those insured has been extended $2 \cdot 3$ years to its present level of $14 \cdot 2$ years.

* Metropolitan Life Insurance Company. Statistical Bulletin, Vol. 42 (June 1961): Voting Population at Record High. Recent Variations in Pnetmonia-Influenza Mortality. Longevity of Industrial Policy-

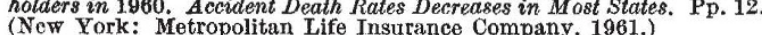

The longevity of American wage-earners and their families has increased more rapidly than that of the general population of the United States. In 1909, the expectation of life at birth of the industrial policy. holders was about six years less than that of the population as a whole. By mid-century the two groups were on a par; at present industrial policyholders have a slight advantage.

The long-term achievements in the conservation of life are accentuated by the very low death-rates now experienced in early life. Mortality of the coloured policy-holders, particularly beyond childhood, is considerably higher than that for whites. Among females, the rates for the coloured are at least double those for the whites from age 23 to the end of the childboaring period. Even though the difference is not as large for males, the ratio of mortality among them for the age-range 24-39 is more than $3: 2$.

Similarly, the average length of life is appreciably greater for white than for coloured policy-holders, and in each race is greater for females than for males. In 1960 , the expectation of life at age 5 years was $70 \cdot 7$ for white females, compared with $66 \cdot 2$ years for coloured females; the corresponding figures for males were 63.8 and 61.9 years.

\section{THE AMERICAN ACADEMY OF ARTS AND SCIENCES}

\footnotetext{
THE Records of the American Academy of Arts and Sciences 1960-1961* includes, as usual, the list of officers and committees, lists of members (including those elected May 10, 1961) with alphabetical index, the statutes and charter of incorporation, and reports submitted at the annual meeting. Special interest is given by the valedictory address of the retiring president, Kirtley F'. Mather, which, under the title "Assay and Perspective" reviews the activi-

* American Academy of Arts and Sciences, Boston. Records of the Academy (including new members elected 10 May, 1061), 1960-61. Pp. 157. (Boston, Mass.; American Academy of A'rts and Sciences, 1961.)
}

ties of the Academy during the four years of his presidency before appraising the present position of the Academy and its responsibilities and opportunities during the next decade. While it was doubtful whether the fullest possible use had been made of the Academy's new house, Mr. Mather thought that the success in developing its publication Daedalus as a journal of ideas and opinion had been outstanding and the Academy had been most successful in its development of conferences on topics of wide importance and interest.

As regards research, 119 grants totalling 91,903 dollars had been made in the past four and a half 
years, compared with 452 applications aggregating more than 500,000 dollars, and the Academy was seeking to increase the number and scope of its awards for recognizing excellence; as yet it had no such award in the social sciences corresponding with its Rumford Medals in the physical sciences, the Amory Prizes in the medical sciences and the Emerson-Thereau Medal in the broad field of literature. The Academy had made no public pronouncement during the period, but Mr. Mather was not satisfied that there had been a suitable theme, and he inclined to think that the Academy was doing what it should more effectively by providing the information to illumine the problems on which policy makers must make their decisions.

As regards the future, Mr. Mather said that the Carnegie Corporation had made a grant of 50,000 dollars for each of the next two years for the continua. tion of the Academy's conference and study programme. It would be necessary in the next four years to assess the value of the Academy's house and the function of the Academy in the State, but he thought that the Academy's outstanding opportunity and responsibility in the next decade lay in serving as a liaison between the community of practical affairs and the practitioners and scholars in the arts and sciences.

\title{
BRITISH COLUMBIA RESEARCH COUNCIL
}

\begin{abstract}
MONG the varied research items described in the seventeenth annual report of the British Columbia Research Council is one into marine borer control (Pp. 16. Vancouver: British Columbia Research Council, 1961). During 1960-61 the stations recording marine-borer breeding were increased to more than thirty as more companies engaged the Division of Applied Biology for protecting logs and wooden installations against losses by borers. By its larval inspection and log-scheduling service, the Division undertook the protection of more than 100 million feet of timber in sea-water storage for Canadian companies and a similar volume for a company in Puget Sound, where the intensity of marine-borer attack is the highest on the North Pacific Coast.

In instances where serious damage by borers would occur before the logs could be used, the rafts were treated chemically by a sprinkling system developed by the Council. During 1960-61 more than 100 sections of high-grade stock were treated in this way prior to hauling from Alaska to Puget Sound; a total of 10 million board feet of wood were chemically treated.
\end{abstract}

One of the outstanding achievements in this field in 1960 was the development of a sonic device for testing the internal condition of pilings. This unit accurately reveals even minor damage by borers in piling. The unit has been used for testing the soundness of piling in wharves on Vancouver Island and in Vancouver Harbour. Operating in conjunction with a diver, 130 piles a day can be examined.

Also developed during the past year was a technique for enshrouding individual piles so that they can be treated chemically to kill embedded borers. This method was developed to protect uncreosoted piles which are used in many logging operations on the coast and as fender piles on many wharfs. The shroud is all plastic to avoid corrosion in sea-water, and can readily be clipped on and off a pile without the use of hooks.

A number of field studies on Bankia setacea, the local teredo-like borer, is being made. These include the susceptibility of different species of wood to attack, the rate of loss by different species, the effect of water temperature on breeding, and studies on the borer itself.

The Canadian Uranium Research Foundation has recently made a grant of 10,000 dollars a year for investigation into the use of uranium compounds as toxicant additives to wood impregnants for marine borers.

\section{RECRYSTALLIZATION OF LEAD AND ZINC SULPHIDES}

\author{
By DR. J. C. NIXON \\ Consolidated Zinc Pty. Ltd., North Melbourne, Victoria \\ AND \\ J. D. HAYTON, D. C. LAWRIE and A. E. TYNAN \\ Australian Mineral Development Laboratories, Parkside, South Australia
}

\begin{abstract}
DEAS advanced in recent years for the formation of conformable ore deposits of base metals (the Broken Hill lead-zine deposit in New South Wales is one of these) imply that the observed ore textures were developed by crystallization or re-crystalliza. tion after initial deposition. The earlier ideas depended in part on the assumption that the mineral textures were original and depositional. Since a useful understanding of the history of these deposits could be of assistance in exploration, some simple experiments were conducted to find out whether the
\end{abstract}

textural condition of lead and zinc sulphides was or was not affected by temperatures which might be attained in deep burial and in high-rank metamorphism.

Chemically precipitated sulphides of lead and zinc were subjected to prolonged treatment in sealed vessels at elevated temperatures. The sulphides were prepared by precipitation with hydrogen sulphide from solutions of lead and zinc salts. The washed precipitates were dried at $90^{\circ} \mathrm{C}$. in an inert atmosphere, and stored in a vacuum desiccator. Samples of each 